\title{
The Role of English Language for High- Achieving Mayan Students in the Yucatan Region, Mexico
}

El rol del idioma inglés en estudiantes de alto rendimiento en la zona maya de Yucatán, México

O papel da língua inglesa em estudantes de alto desempenho na área maia de Yucatán, México

Miguel Antonio PAT LÓPEZ

Universidad Autónoma de Yucatán, México.

miguel.patl@correo.uady.mx

https://orcid.org/0000-0002-4864-0299.

Pedro Antonio SÁNCHEZ ESCOBEDO

Universidad Autónoma de Yucatán, México.

psanchez@correo.uady.mx https://orcid.org/0000-0002-0564-3502.

Received: 13/04/2019

Accepted by peers: 16/08/2019
Sent to peer review: 24/04/2019

Approved: 22/08/2019

DOI: 10.5294/laclil.2019.12.1.3

To reference this article (APA) / Para citar este artículo (APA) / Para citar este artigo (APA) Pat, M. A., \& Sánchez, P. A. (2019). The role of English language for high-achieving Mayan students in the Yucatan region, Mexico. Latin American Journal Of Content \& Language Integrated Learning, 12(1), 46-71. DOI: https://doi.org/10.5294/laclil.2019.12.1.3 
ABSTRACT. The purpose of this research was to identify the role of the level of proficiency in the English language with high-performing third-year students in the Mayan area of Yucatán, near a tourist region called the Riviera Maya. The aim was also to explore the relationship between learning a second language and the subsequent overall improvement in the academic performance of students. These 114 high-achieving students were selected from 1177 students who had taken a standardized English test administered in seven middle schools in the region. Subsequently, individual interviews were conducted with the 21 students with the highest level of English and a focus group of ten students with low-level scores. The results showed an improvement in the English language, as well as its influence in reaching academic prowess in other subjects. This initial study indicated that the reinforcement of English language skills had broader benefits on other academic performance.

Keywords (Source: Unesco Thesauros): English; Maya; middle schools; academic achievement; high achievers; second language instruction; bilingual education.

RESUMEN. El propósito de esta investigación fue identificar el papel del nivel de competencia en el idioma inglés con estudiantes de tercer año de alto rendimiento académico en la zona maya de Yucatán, cerca de la región turística llamada Riviera Maya. El objetivo también fue explorar la relación entre el aprendizaje de un segundo idioma y la mejora general posterior en el rendimiento académico de los estudiantes. Se seleccionaron 114 participantes de 1177 estudiantes de siete secundarias de la región, a los cuales se les administró un examen de inglés estandarizado. Posteriormente, se realizaron entrevistas individuales con los 21 estudiantes con el nivel más alto de inglés y un grupo focal de diez estudiantes con puntajes de bajo nivel. Los resultados mostraron una mejora en el idioma inglés, así como la influencia de este para alcanzar destrezas académicas en otras asignaturas. Este estudio indicó que el refuerzo de las habilidades del idioma inglés tiene beneficios más amplios en otras áreas académicas.

Palabras clave (Fuente: tesauro de la Unesco): inglés; maya; escuela secundaria; desempeño académico; alto rendimiento; educación bilingüe; enseñanza de una segunda lengua.

RESUMO. O objetivo desta pesquisa foi identificar o papel do nível de proficiência em inglês com alunos do terceiro ano com um alto desempenho acadêmico na área maia de Yucatan, perto de uma região turística chamada Riviera Maya. O objetivo também foi explorar a relação entre a aprendizagem de um segundo idioma e a subsequente melhoria geral no desempenho acadêmico dos estudantes. 114 participantes foram selecionados entre 1177 estudantes de sete escolas de ensino médio da região, que receberam um teste de inglês padronizado. Posteriormente, foram realizadas entrevistas individuais com os 21 alunos com o mais alto nível de inglês e um grupo focal de dez alunos com notas baixas. Os resultados mostraram uma melhora no idioma inglês, bem como sua influência no alcance de habilidades acadêmicas em outras disciplinas. Este estudo indicou que o reforço das habilidades em inglês traz benefícios mais amplos em outras áreas acadêmicas.

Palavras-chave (Fonte: tesauro da Unesco): inglês; maia; ensino médio; desempenho acadêmico; alto rendimento; educação bilíngue; ensino de segunda língua. 


\section{Introduction}

\section{The role of English education in Mexico: A brief outline}

English is important at a worldwide level: It is used in areas as diverse as education, economics, communication, business, and many more. For this reason alone, it would be reasonable to expect that teaching this language in Mexico would be as important as Spanish or Mathematics. However, Mexican students present a low level of proficiency in this language, and therefore it is necessary to establish an alternative perspective that could offer support for the benefits of having the skills of production and reception of the English language. This has the potential to help the monitoring and execution of educational programs focused on teaching English.

The results of Education First (2018) and Mexicanos Primero (2015) indicate that low levels of English language proficiency proliferate throughout the country. According to Education First (2018), Mexico is ranked 57 out of 88 countries with 49.76 points. This is the result of a test administered to 1.3 million participants and quantifiably demonstrates a low level of language proficiency. Sweden was ranked first with 70.72 points, followed by the Netherlands, Singapore, Norway, and Denmark (Education First, 2018). However, if we compare Mexico with other participant Latin American countries, it ranks ninth out of 17, with Argentina in first place with 57.58. Amongst Mexico states, the first place with 54.53 points was obtained by Mexico City, while Yucatan obtained eighth place with 51.04 points.

Mexico City and Jalisco were the states with the highest rate of achievement, positioned at the middle level in the scale. Yucatan, the specific state of this study, shows average English skills in Mexico, but a low level according to the English scale of Education First.

In addition to these results from Education First, Mexicanos Primero administered an English test in 2015 called "Examination of the Use and Understanding of the English Language for Secondary School Graduates" in some state capital cities in order to establish results. In the case of Yucatan, the test was focused on Merida, irrespective of 
other cities that could provide valuable information from other points of view, as they are in areas of growing tourism and their inhabitants have direct communication with people from other countries. There are many Mayan-speaking areas, which could influence the learning and development of other languages. For this reason, among others, this project focused on the eastern part of the state of Yucatan, specifically in the public middle schools of Valladolid, Temozón, Calotmul, and Tizimín.

With respect to English language levels in Mexico, the low saturation of English language in basic education has several origins: from learning problems that affect students' learning of English, to poor teacher training, absence of appropriate materials, lack of consistency in the courses, and more (Ricoy \& Álvarez, 2016). In fact, the first attempt to incorporate the English language for fifth and sixth year in elementary schools countrywide was in 2005 through the "Enciclomedia Program," and that failed due to lack of teacher training among other reasons (Ramírez, Pamplón, \& Cota, 2012).

In 2009, the "National Program of English in Basic Education" was implemented from kindergarten to high-school education. However, it was canceled in 2014 when the results were not as expected. Then, the English projects for basic education appeared in the "Program for the Strengthening of the Quality of Basic Education," which in 2016 was renamed the "National English Program, PRONI" (Rámirez \& Sayer, 2016). Then, during the 2018-2019 school year, the plans resumed based on the 2018 educational model (Secretaría de Educación Pública, 2017).

The disadvantage that most Mexican students have today is that they started studying English in middle school. At this educational level, students are exposed to the English language for three hours a week for three years, while in high school they study for only a few semesters depending on the modality they have chosen. For example, if they went to a high school incorporated to the Universidad Autónoma De Yucatán, they would study it for five semesters, but if they went to Colegio de Bachilleres de Yucatán (COBAY), they would study it for four semesters.

This shows that a strong association is not established in the teaching of English language in Mexican educational levels, especially from middle school to high school, because in each course, students start with the same topics and the same English level. Furthermore, 
the teaching methodologies and strategies are lacking in both practice and a curricular follow-up, since, upon enrolling in high school, students are taught the same contents studied during middle school, starting from the lowest level (Ramirez, Pérez, \& Lara, 2017). This situation has led to the linguistic skills of the students being deficient, despite the many years of formal English study. Moreover, when students study at the university level, they have difficulty because some schools require a B1 level or higher based on the Common European Framework of Reference for Languages (CEFR).

With this information, it can be inferred that public policies related to education are not given adequate follow-up with every federal government change, which results in uncertainty about the development of the new English project that was resumed in elementary schools in the 2018-2019 school year, as well as the 2018-2024 public policies on English language by the federal government.

\section{Research hypothesis}

Learning a second or third language provides several benefits for people and, in the case of the Yucatan students, having a good second language level would mean optimizing their education. Some studies in the literature validate this approach; for example, some results show advantages of bilingualism that indicate better attention and concentration (Krott, as cited in Hays, 2016), as well as better control of visual attention (Friesen, Latman, Calvo, \& Bialystok, 2015), and the optimal development of creative thinking, generally as mathematicians (Leikin, 2013).

It can be considered that the main deficiency in English language teaching in the educational system of Mexico can be attributed to the educators themselves, as they do not receive a good English language education either. Therefore, due to the teachers' lack of proficiency in English, at the end of the school year, students finish the English course, but they show no progress.

With this in mind, the central research question is: How is the acquirement of English language related to the academic performances of high-achieving third-year students of middle schools in Yucatán? This was procured with the purpose of contributing with new perspectives for English language learning. 


\section{Method}

According to Krashen (1984), the theory of second language acquisition is based on five hypotheses: the first one was Learning vs. Acquisition regarding the conscious or unconscious development of the language; the second one was the Natural Order, focused on the grammatical structures that are learned first; the third one was the Monitor, where the conscious process reviews and corrects what is communicated in the second language based on what has already been learned; the fourth one was the Input Hypothesis, i.e., the entry of understandable data in which the person is in contact with the second language; and finally, the fifth hypothesis was the Affective Filter, which considers this factor as a trigger for motivation in language acquisition.

In agreement with Krashen's (2003) hypothesis, people learn a second language when they receive the information in an understandable and clear way, also considering that their affective filters are favorable for processing information. That is, understandable data can make the acquisition of a second language effective and real.

The second language acquisition theory can be seen not only from the how or when the second language acquisition occurs, but also from the reasons and purposes for learning it (Barrantes, 2015).

However, the objectives and structure of this research were based on Stern's (1983) Second Language Acquisition theory. This argues that the acquisition and learning of a second language is a complex and multidimensional phenomenon related with the following characteristics: the social context (how society influences language and behavior), the characteristics of the student (learning skills and personality), learning conditions (the school and community infrastructure), learning processes (teachers' strategies and methodologies) and the result of learning (the reason they are learning the language).

For the phases of identification and characterization of high-achieving students in middle schools of the Mayan zone of Yucatan, a transversal quantitative approach was chosen. The qualitative approach for the third phase endeavored to understand the role and value of the English language for lifelong learning. The process was divided into three phases: 
Identification of the students considered as high achieving. Implementation of an English test developed by Universidad Autónoma de Yucatán to determine the students' proficiency level.

Semi-structured interviews and focus groups with some of the participants from the first and second phase (See Appendix I \& II).

According to the objectives of this study, the approaches to research used were qualitative in the first and second phases and quantitative in the third phase. Thus, the research is structured as a sequential explanatory design (Creswell \& Plano, 2007). The first phase located and characterized the high-achieving students according to teacher nomination and used a checklist to select the participants who would progress to the next phase. This second phase consisted of administering an English test with the objective of placing the students in the appropriate CEFR levels. The third phase consisted of semi-structured interviews and focus groups with some of the participants in order to understand the results better.

When considering the objectives and the procedures, it was decided to use a combination of quantitative and qualitative methods (Hamui-Sutton, 2013). This allowed in-depth analysis and the ability to see the problem from different perspectives (Tashakkori \& Teddlie, 2003), where both objective and subjective realities were of equal value (Tashakkori \& Teddlie, 2009).

\section{Data analysis}

This section describes how the data obtained was analyzed and its importance for the proposed future research. It uses a combination of reflection, analysis, and reasoning in order to understand the situation. First, an analysis was made of the information obtained from the checklists to understand the characteristics of the high-achieving student, and this data was collected using the statistical SPSS software. Likewise, the results of the standardized test were collected and classified according to the CEFR level of the students.

Subsequently, content analysis was utilized as a technique for the interpretation of the data collected in the qualitative phase. In this case the content of the results, if interpreted correctly, allowed collection of information about - and the knowledge of - the individual student and 
of society. According to Krippendorff (1990), it is "a research technique designed to formulate, from certain data, reproducible and valid inferences that can be applied to its context" (p. 28).

For the content analysis, the Atlas.ti software was used to encode the information and categorize it in order to establish networks and links between the answers.

\section{Research setting}

Yucatán is one of the 32 states of Mexico. It is divided into $106 \mathrm{mu}$ nicipalities, and its capital city is Mérida. Yucatán is located on the northern part of the Yucatán Peninsula. The Campeche State is located southwest, and Quintana Roo is located southeast, while bounded to the north by the Gulf of Mexico.

The eastern part of the state of Yucatan is characterized by the Mayan population, as well as the tourism sector, which is being developed by the government. The research was carried out in federal, state and technical middle schools in some municipalities in this area, specifically in Valladolid, Temozón, Calotmul, and Tizimín.

\section{Valladolid}

This small city has 80,313 inhabitants (INEGI, 2015a), 44,686 of whom speak an indigenous language, corresponding to $55.64 \%$ of the total population. In this latter group, $10.86 \%$ did not speak Spanish. In addition, $77.88 \%$ of the total population of this municipality was considered indigenous (INEGI, 2015b). In the field of public and basic education in 2010, the municipality had 46 preschools, 63 elementary schools, 18 indigenous elementary schools, 26 middle schools, eight high schools and eight job training schools (CONEVAL, 2010).

\section{Temozón}

With a population of 15,503 inhabitants (INEGI, 2015a), the second research region was Temozón, of this populace, 12,495 , or $80.60 \%$, spoke an indigenous language and within this group, $8.75 \%$ did not speak Spanish. In essence, this meant that $97.28 \%$ of the total population indicated indigenous origins (INEGI, 2015b). In 2010, in the areas of public and basic education, there were 12 preschools, 16 elementary schools, 
eight indigenous elementary schools, nine middle schools, and one high school (CONEVAL, 2010).

\section{Calotmul}

The third place, Calotmul, had 3992 inhabitants (INEGI, 2015a); 2317 (or $58.06 \%$ ) of them spoke an indigenous language, and $1.95 \%$ of this group did not speak Spanish. Moreover, $92.16 \%$ of the municipality's citizens were considered of indigenous origin (INEGI, 2015b). According to the CONEVAL report based on the 2010 census, there were four preschools, four elementary schools, three middle schools and one high school.

\section{Tizimín}

The final research location was Tizimín, with a population of 77,621 inhabitants (INEGI, 2015a). The population that spoke an indigenous language according to the INEGI (2015b) was 30,186 , or $38.89 \%$, of whom $2.75 \%$ did not speak Spanish. From the total number of inhabitants, $74.04 \%$ were of indigenous origin. In 2010, the city had 70 preschools, 78 elementary schools, 18 indigenous elementary schools, 32 middle schools, 12 high schools, and three job training schools (CONEVAL, 2010).

\section{Results}

\section{Stage I. Quantitative approach}

\section{Phase I. Identification of participants}

The participants of this research project were third-year middle school students from seven schools in eastern Yucatán across four municipalities: three schools from Valladolid, one from Temozón, one from Calotmul, and two from Tizimín. From these schools, 1177 students between the ages of 14 and 17 participated in the research project.

The teachers, who also acted as counselors for each group, identified and selected the participants who, in their opinion, matched, the characteristics of a high-achieving student. This method was acceptable because the teachers spent more time with them in the class- 
rooms and had first-hand information about their performance and development (Chávez, Zacatelco, \& Acle, 2014).

Group counselors or teachers worked with the participants during the 2017-2018 school year, which allowed them to have information about the students, such as behavior, performance in the various academic subjects, learning styles, amongst others. It is important to mention that nominations of students by teachers were conducted after an explanatory meeting in which the characteristics of high-achieving students were described and any ensuing doubts about the project had been assuaged. In addition to this, a checklist was used in order to help to choose the participants and have better results in the teacher nominations.

The checklist was used to identify the participants whose profile matched the characteristics of a high-achieving student. This checklist included items on academic performance, motivation, learning style, concentration, teamwork, criticality, creativity, study habits, among others, which were based on the high-achieving characteristics established by Jiménez and Álvarez (1997), Tarver and Curry (1992), Montes and Lerner (2011), Zavala (2004), and Edel (2003).

\section{Characteristics of high-achieving students.}

All the selected participants fulfilled the positive characteristics of the checklist in most of the 20 items. These characteristics included descriptors related to their knowledge of different subjects: whether they were consumers of relevant information, were considered to be autonomous learners, obtained good grades, used the means at their disposal optimally, had positive self-concept, were curious, as well as their participation and development in class.

Most of the participants gave positive answers in the checklist, but some of them with some specific characteristics gave negative answers. For example, 16 students mentioned they were bad in the organization of the activities and materials, representing $14 \%$ of the total number of high-achieving students. The second most striking characteristic was that of 13 students, or $11 \%$, represented mentioned they had bad behavior. Other negative data indicated that $8 \%$ did not participate enough in classes, while $7 \%$ interacted in a limited way with their classmates. 
High-achieving students.

After analyzing the nominations and the checklist, 114 high-achieving students were identified, 90 females and 24 males. This represented 9.6\% of the total number of students enrolled in the third year of the seven middle schools (see Table 1 below).

Table 1. Middle schools in the Maya Region

\begin{tabular}{|c|c|c|c|c|}
\hline Middle school & Location & $\begin{array}{c}\text { Total number } \\
\text { of students }\end{array}$ & $\begin{array}{c}\text { High-achieving } \\
\text { students }\end{array}$ & $\begin{array}{c}\% \text { per } \\
\text { school }\end{array}$ \\
\hline José Inés Novelo & Valladolid & 165 & 14 & 8 \\
\hline Antonio Mediz Bolio & Valladolid & 259 & 20 & 8 \\
\hline Técnica \#6 & Valladolid & 196 & 19 & 10 \\
\hline Técnica \#39 & Temozón & 130 & 16 & 12 \\
\hline Técnica \#43 & Calotmul & 38 & 9 & 24 \\
\hline Miguel Barrera Palmero & Tizimín & 197 & 8 & 4 \\
\hline Técnica \#4 & Tizimín & 192 & 29 & 15 \\
\hline Total & & 1177 & 114 & 9.6 \\
\hline
\end{tabular}

Source: Own elaboration.

\section{Phase II. English language ability test}

The second phase of the quantitative stage focused on determining the English proficiency level of the middle-school, third-year participants, and a standardized test was administered to ascertain this. The objective was to determine the level of reading and writing competence, listening comprehension, and oral expression in English.

The standardized tests measure specific variables (Jornet \& Suárez, 1996) and are administered under uniform conditions according to established procedures (Woolflok, 2010), which facilitates the collection and interpretation of information (Jornet, 2017).

At this stage, the selected students took the prototype test of the Institutional English Program of Universidad Autónoma de Yucatán, which is a standardized English level test that prospective students need to take. With the results of this test, the students received their scores and explanations of their results according to the standards of the Common European Framework of Reference (CEFR). 
According to the English test results, 15 students were at A1 level, 78 at A2 level, 19 at B1 level, and two at B2 level. Moreover, 15 female students were at the B1 and B2 levels as opposed to six male students, which shows that the girls were almost three times as likely to be high-achieving students and would have a higher level of English.

The next stage was with the participants with B1 and B2 levels identified. A semi-structured interview was conducted individually that also included the completion of a socio demographic data sheet.

Also, there was a focus group of students with the lowest A1 level in order to ascertain their ideas and opinions on what factors had influenced their level of the English language. In addition to this, their suggestions about their ability to reach the higher levels of English and their subsequent expectations were documented.

\section{Stage II. Qualitative approach}

\section{Phase III. Twenty-one B1 and B2 participants}

One of the questions was about self-perception of their own performance as students, and these answers were grouped according to the opinion of each participant. Two considered themselves regular students who sometimes had excellent scores but who obtained regular grades other times because they did not study hard or they had failed to turn in some projects. Ten perceived themselves as good students because they did all the assigned homework and projects and felt responsible for what they did. Eight believed that they were very good, since they felt committed to the school and they liked to get good grades. Only one perceived himself as excellent because of his dedication and responsibility, and he overtly stated that most of the subjects were easy for him.

They were also questioned about whether their academic performance has been constant since elementary school or if they had perceived changes. Twelve said that they had maintained good gradepoint average (GPA) scores since elementary school simply because they liked studying and did not consider it difficult. Seven indicated that they had improved as students after enrolling in middle school because they knew that, at this level of education, there were more 
teachers, more subjects and more classmates, and therefore they had to work harder. Two indicated that they felt their level decreased compared to that of elementary school or the first years of middle school, because, unlike then, they did not study much for exams or presentations, although they kept getting good grades.

Another question was about languages; students were asked if they spoke other languages besides Spanish and English. Seventeen answered that they only spoke those languages, while four said they also spoke Maya. This is interesting information because in the region where the research was conducted is considered to be Maya area, but the majority of these high-achieving students did not speak it. There were different factors responsible for this, but the most pertinent was that students said that some family members speak Maya at home (see Excerpt 1), but the adults recommended using Spanish and learning English in order to better secure a job in the future.

\section{Excerpt 1}

My parents told me that I need to speak Mayan, because my grandmother who lives in my house only speaks Mayan. I don't speak Mayan, but I comprehend the words or phrases she says, so I understand it, but I can't speak it.

The next question in the interview was how they'd learned English. Three stated that they had taken private classes, which they had first attended after starting middle school because it was already a compulsory subject and because they liked the language. Three indicated that they had started learning English in elementary school with songs and basic vocabulary provided by the teachers. Four said they learned due to family influence, because their parents or siblings spoke the language and would practice with them, as well as remind them that, if they learned English, they could have better jobs in the future. Three stated that they had learned through TV series, music, and films, watching with and without subtitles (see Excerpt 2). In the case of music, they learned songs through repetition and by looking for the meaning of the lyrics. 


\section{Excerpt 2}

It was easy to learn it because besides that I like it, I like the songs in English. I was curious to know what the songs say, what they meant. I remember that I looked for the lyrics in internet and this way I was learning words, also watching movies and series subtitled in English. When you see, listen and read you learn more words.

The following question had to do with whether any of their family members spoke English. Ten indicated that one or more members of their nuclear family did. Three indicated that one or more of their extended family had a good English proficiency level. One indicated that both in their nuclear family and their relatives there were people who spoke the language. Finally, seven indicated that nobody in their family spoke English. In all, fourteen students were related to people who speak the language because of their job or academic background. They also answered that these people motivated them to learn, and on occasion, practiced the language with them.

\section{The role of English}

Four of the participants expressed that English helped them in many ways in school, for example, to search out topics that they did not understand in classes. They found it easy to look for information in articles or webpages written in English, and they even watched videos on YouTube for explanations on specific topics. Five participants indicated that the language allowed them to know what is happening around the world, as a student stated in Excerpt 3.

\section{Excerpt 3}

Have a good level of English helps me to learn other things that happen in other more advanced countries. It helps me to know about other perspectives of the world.

Six participants added that they could watch the news, read articles or notes on social media that were not in Spanish. According to them, this caused them to think differently or see things from other points of view. Four considered that, with a high level of English, they 
would have a better future in some professions that would require it and, for that reason alone, they could decide what to study at university. Finally, eight indicated that it helped them to communicate with more people (see Excerpt 4), in that they could socialize, learn about more cultures and make friends from many places.

\section{Excerpt 4}

I consider that speak English influences in our way to see the world, because is an important language and it can give a job opportunity. It influences my communication, it allows to socialize with more people, is something very cool. Socialize with some foreigner to know about their hometowns, what they do, etcetera.

Another question was about how the English language could help them in the future. Four stated that they would like to do some academic exchange or study abroad programs when they are in high school or university. They understood that English would be a requirement for what they consider to be higher education and they knew that they would have to complete certain steps in order to achieve their goal. Six commented that English would serve them in their academic and professional development, because they would be able to consult books or articles that are only in English. They also said that it would be easier to use software that was not in Spanish (see Excerpt 5).

\section{Excerpt 5}

In mechatronics, the instructions are in English and in the modern editing programs the instructions are in this language.

On the other hand, eleven students indicated that they would be able to get a job because they considered English to be a requirement for the best jobs. These students considered that, in the future, they would be able to offer their services to foreigners and, thus, increase their profits, because foreigners could pay more and could be charged in the more lucrative dollar. 


\section{Ten A 1 participants}

In the A1 level focus group, ten students were asked some questions about which factors could help them to improve their English level. The students agreed that more lesson hours would be helpful, since there were many students in a class and not enough time to practice; as a result, only some of them were able to participate and it was almost always the same students or those at a higher level. One possible solution, as some students commented, would be if they could attend extra classes in the afternoons, if the school offered them.

Students also requested other teaching methods from the teachers because, although the classes were not bad, they thought that teachers always did the same thing and should talk more to improve diction and fluency. Another point was about the use of software or phone apps so that they could practice more at home by themselves and thus would improve their English level. They suggested that the teacher should recommend which apps or programs worked and were worthwhile. This was because, if they went to the App Store of their phones, they could find an extensive catalog of apps, but they did not know which ones worked and which did not.

Another aspect mentioned was that students should commit to studying and practicing the language if they really wanted to learn it. Although it was true that they got good grades in English every two months, they were aware that it was because, before the tests, they studied all their notes, including vocabulary, tenses, and structures, yet they could not put his information together to express ideas in written and oral formats. Finally, they commented that they would also learn more if there were exchange programs with students from other countries who spoke English, or who only visited them at school to talk and listen to other types of pronunciation.

Five participants were aware of the level of English required by many companies when hiring, so they pointed out that, if they improved their level upon finishing their studies at the university, they could find well-paying jobs. Twenty percent of the students indicated that if they had a higher level of English language, they would have access to more information that they could use in their school. And finally, thirty percent said that if their level of English was higher, they 
could enter better universities that require certain levels of language, and they could even think about studying in the United States, Canada, or England.

In 2015, the association Mexicanos Primero indicated a non-existent level of English in Yucatán in middle-school students; however, its results focused only on Merida, the capital of the state. This research considered other cities and towns in the state and found that at least 99 students were placed in the A2 level or higher.

As previously specified, Stern's theory has some characteristics that influences in the acquisition of a second language, namely the social context, the student characteristics, the learning conditions, learning processes, and learning results. These characteristics were identified in this research. For example, the learning processes focuses on students' mental strategies, techniques and operations by learning the language, not only in educational settings, but also in the context where they were exposed to the second language. This can be seen in students at the B1 and B2 levels, who, after studying English, positively influenced their development in the other middle-school subjects, causing significant improvement in their academic performance. This is because, when students have good skills in another language, it allows them to have access to different sources of information, which helped them to better understand the topics they study every day (see Excerpt 6).

\section{Excerpt 6}

In English we have to learn many words, at first I wrote down and memorized the vocabulary, however, it became easier for me to learn the words, their definition and their meaning in Spanish, which has also helped me learn new words from other subjects such as science or geography.

In addition to Stern's theory, it is important to mention Marian and Shook (2012), who indicate that the improvement of the cognitive and sensory process, leads the bilingual person to better process infor- 
mation in their environment, which brings clear signals to learn and improve in areas such as memory, visual spatial ability, and creativity. Through their answers, students also pointed out that when they have a good level of English, this influences in their grades because they perceive English as easy.

\section{Excerpt 7}

English has precise structures, it has an order, which allows the idea to be clear and direct. This influences when I write in Spanish, since I know that I must follow a structure so that my writing makes sense and is not filled with unnecessary information. My Spanish and history teachers have told me, they say I write very well.

The sensory process appeared when students commented that the structuring of phrases and sentences allowed them to compare and improve their writing in Spanish, since it made them aware of the grammatical rules (see Excerpt 7). Although they knew that the languages were not the same, the English order of expression, communicating messages or to clarification of main ideas, helped them in subjects such as Spanish, History, and Ethics. This led them to think about learning a third or fourth language in the future since they consider that they have a good understanding and a solid foundation to learn a language according to their experiences in learning English.

The objectives of each course and levels should be clearly identified. Furthermore, the students indicated that, if they obtained the B1 level approved by the Ministry of Education, they would be better prepared for high school or university because it would allow them to study in universities where the curriculum requires English, such as Universidad Autónoma de Yucatán or the technological institutes of Valladolid and Tizimín. They also do not rule out the possibility that English would help them to get scholarships to study in the United States or in a European country, thus gaining experience and a better education.

Stern (1983) also established the importance of the learning condition that focuses on the influence of the educational context. For example, for teaching English as a Foreign Language (EFL), courses would focus on content, objectives, procedures, materials, and evaluation; while teaching English as a Second Language (ESL), students are 
exposed to the target language not just in the classroom, but in their daily lives. In the case of participants, two of the students have learned EFL, because there are far less people who speak English in the region than people who speak Spanish or Mayan, and therefore they did not have the opportunity to practice the second language. Their answers show that students want to learn about other cultures and expand their minds, because when they read books or post in social media, they can identify places, lifestyles, different communication styles, social behaviors and more, as these say a lot about a country, which is transmitted through its language.

On the other hand, the A1-level students indicated that their interest in improving their proficiency in English was to know more about the world, learn new things and improve their qualifications. Students with a B1 and B2 level were aware that a higher proficiency in English would give them better opportunities to enroll and study at their university of choice.

A corresponding study in an ESL context in Melbourne provided the link between English and academic development. In this study, the success was focused on certain areas, such as linguistics and literature, and positively identified that having two or more languages gave the students self-confidence (Bayliss, 2006). The Yucatan students who said English had had an impact on their lives overtly mentioned such self-confidence, and some identified that, by improving their proficiency in English, they could communicate better, not only in that language, but also in Spanish. This was because, when they discussed topics or shared their opinions in other subjects, they felt confident in doing so because they were able to express themselves in another language, and therefore it would be easier in Spanish. Some students considered that it is often difficult to pronounce English words because it is very different, but that they had the goal to overcome this fear of mispronunciation.

Another characteristic of Stern's theory relates to the cognitive aspects of each individual. These include general aspects such as age and sex, but also variables such as learning skills, aptitude for language learning, previous experiences in second language acquisition, learning styles, attitudes, motivation and personality. This was also reflected in the answers of all the students who established the relationship be- 
tween the acquisition of the English language and their future, thinking that they would have more contact with people from all over the world and that they could even enroll overseas in universities where English is spoken. However, they considered that even if they were not English-speaking locations, universities should always give priority to people who have a certain level of English since, in most cases, having a good proficiency level of the language is a requirement.

With respect to job expectations, the students considered that having a high level of English meant that they could work in the future with or for foreigners, but not only in the sales of tourist services like their parents. If they could graduate as lawyers, doctors or business administrators, they would be able to communicate with native English speakers as well as live in English-speaking regions because of investment in their own business. In addition, they could provide their services directly to tourists and they would not need the services of a translator or an interpreter.

Students also stated that having a high level of English would make it easier for them to work in the tourism sector, both in Yucatan due to the growing number of tourists visiting the area, or in the Riviera Maya in Quintana Roo, where accountants, engineers, chefs, administrative staff and doctors are highly sought after. The students commented that, if they could not earn a degree and merely graduate from a regular or technical high school, with high levels of English, they could obtain a certificate after taking different courses to become animators, bartenders, tourist guides, snorkel instructors, and more.

These ways of thinking about English and future employment was a common feature of this research and is another part of Stern's theory-that of social context. Stern (1983) noted that the individual's environment influences the learning of a language, covering sociolinguistic, sociocultural and socioeconomic aspects. Students noted that, upon completing their studies and entering the job market, the first choice would be the candidates with the highest proficiency in English, since companies seek employees who have the best skills and aptitudes. These students also mentioned that, if they graduated from university and if their level of English increases, they would receive better economic benefits. Therefore, these students considered that English 
language skills would give them better opportunities to work in the future, first as employees, but that, through experience and by expanding their networks, they could venture into self-employment.

These high-achieving students demonstrated in the interviews that they are well informed about the link between their level of English and their academic performance. Their plans were to continue studying, and some were already analyzing the career they could choose, considering the reality of their economic situation, the possibility of acquiring scholarships and the universities in close proximity to their communities.

\section{Conclusion}

In summary, academically, for students A1, B1 and B2, a good level of English would mean open access to information at an international level, doing school exchange programs in other countries, communicating with more people, being informed about what is happening around the Internet, getting better grades and expressing themselves in many ways.

These students consider that skills with the second language will provide them better opportunities to work in the future, first as employees, but that, with experience and networking, they can venture to be their own bosses in any area. This research also found that these students from these four municipalities in Yucatán are dedicated to their academic development and want to study at university. They overtly stated that, based on the influence of relatives, friends and their own self-motivated research, English would be an important key to their future. That was the main reason why A1 level students wanted to increase their English level for the university and their subsequent job, while B1 and B2 level students were already considering careers where the language can serve them to obtain better benefits for their well-being. They were cognizant that they should continue improving their English language level and, furthermore, they would also be interested in learning other languages, including Maya. 


\section{References}

Barrantes, L. (2015). ¿Cómo establecer un puente entre la teoría de adquisición de las segundas lenguas y la justicia social? Letras, 195212. Retrieved from https://www.revistas.una.ac.cr/index.php/letras/article/view/8636

Bayliss, A. (2006). IELTS as a predictor of academic language performance. Australian International Education Conference (pp. 1-12). Retrieved from https://pdfs.semanticscholar.org/545d/f30dada9c00f1029b812db812e799ba9e8a8.pdf

Chávez, B., Zacatelco, F., \& Acle, G. (2014). ¿Quiénes son los alumnos con aptitud sobresaliente? Análisis de diversas variables para su identificación. Actualidades Investigativas en Educación, 14(2), 1-32. DOI: https://doi.org/10.15517/aie.v14i2.14828

Creswell, J., \& Plano, V. (2007). Designing and conducting mixed methods research. Thousand Oaks, CA: SAGE.

CONEVAL, C. N. (2010). Informe anual sobre la situación de pobreza y rezago social. Retrieved from https://www.gob.mx/cms/uploads/attachment/ file/47235/Yucatan_102.pdf

Edel, R. (2003). El rendimiento académico: concepto, investigación y desarrollo. REICE. Revista Iberoamericana sobre Calidad, Eficacia y Cambio en Educación, 1(2). Retrieved from https://revistas.uam.es/index.php/ reice/article/view/5354

Education First. (2018). EF SET. Retrieved from https://www.efset.org/es/faq/

Friesen, D., Latman, V., Calvo, A., \& Bialystok, E. (2015). Attention during visual search: The benefit of bilingualism. The international journal of bilingualism: cross-disciplinary, cross-linguistic studies of language behavior, 693-702. DOI: https://dx.doi.org/10.1177/1367006914534331

Hamui-Sutton, A. (2013). Un acercamiento a los métodos mixtos de investigación en educación médica. Investigación en Educación Médica, 2(8), 211-216. Obtenido de http://www.redalyc.org/articulo. oa?id=349733226006

Hays, B. (2016, September 9). Learning, speaking a second language aids attention and focus. Retrieved from https://www.upi.com/Science_ News/2016/09/09/Learning-speaking-a-second-language-aids-attention-and-focus/8891473437511/ 
INEGI. (2015a). Encuesta intercensal. Retrieved from http://www.beta.inegi. org.mx/app/areasgeograficas/?ag=31\#tabMCcollapse-Indicadores

INEGI. (2015b). Panorama sociodemográfico de Yucatán 2015. Retrieved from http://coespo.yucatan.gob.mx/general/31_Panorama_Yuc.pdf

Jiménez, C., \& Álvarez, B. (1997). Alumnos de alta capacidad y rendimiento escolar insatisfactorio. Revista de Educación, (313), 279-295. Retrieved from http://www.mecd.gob.es/dctm/revista-de-educacion/articulosre313/re3131300461.pdf?documentId=0901e72b81272c1a

Jornet, J. (2017). Evaluación estandarizada. Revista Iberoamericana de Evaluación Educativa, 10(1), 5-8. Retrieved from https://revistas.uam.es/ index.php/riee/article/viewFile/7590/7890

Jornet, J., \& Suárez, J. (1996). Pruebas estandarizadas y evaluación del rendimiento: usos y características métricas. Investigación Educativa, 14(2), 141-163. Recuperado de https://www.uv.es/gem/archivos/ RIE14.PDF

Krashen, S. (1984). Second language acquisition and second language learning. Exeter, CA: Pergamon Institute of English.

Krashen, S. (2003). Explorations in language acquisition. Portsmouth, NH: Heinemann.

Krippendorff, K. (1990). Metodología de análisis de contenido: teoría y práctica. Barcelona, Spain: Grupo Planeta.

Leikin, M. (2013). The effect of bilingualism on creativity: Developmental and educational perspectives. International Journal of Bilingualism, 431-447. DOI: https://doi.org/10.1177/1367006912438300

Marian, V., \& Shook, A. (2012, October 31). The Dana foundation. Retrieved from http://dana.org/Cerebrum/2012/The_Cognitive_Benefits_of_being_Bilingual/

Mexicanos Primero. (2015). Sorry. Aprendizaje del inglés en México. Retrieved from http://www.mexicanosprimero.org/images/stories/sorry/Sorry-digital-ok.pdf

Montes, I., \& Lerner, J. (2011). Rendimiento académico de los estudiantes de pregrado de la Universidad EAFIT. Retrieved from http://www.eafit. edu.co/institucional/calidad-eafit/investigacion/Documents/Rendimiento\%20Ac\%C3\%A1demico-Perrspectiva\%20cuantitativa.pdf

Rámirez, J., \& Sayer, P. (2016). The teaching of English in public primary schools in Mexico: More heat than light? Archivos Analíticos de Políticas Educativas, 24, 1-22. Arizona State University. Arizona, 
United States of America. Retrieved from http://www.redalyc.org/ pdf/2750/275043450125.pdf

Ramírez, J., Pamplón, E., \& Cota, S. (2012). Problemática de la enseñanza del inglés en las primarias públicas de México: una primera lectura cualitativa. Revista Iberoamericana de Educación, 2-12. Retrieved from https://rieoei.org/historico/deloslectores/5020Ramirez.pdf

Ramírez, L., Pérez, C., \& Lara, R. (2017). Panorama del sistema educativo mexicano en la enseñanza del idioma inglés como segunda lengua. Revista de Cooperación, 15-21. Retrieved from http://revistadecooperacion.com/numero12/012-02.pdf

Ricoy, M., \& Álvarez, S. (2016). La enseñanza del idioma inglés en la educación básica de personas jóvenes y adultas. Revista Mexicana de Investigación Educativa, 385-409. Retrieved from https://www.redalyc. org/pdf/140/14045395003.pdf

Secretaria de Educación Pública. (2017). Modelo educativo para la educación obligatoria. Retrieved from https://www.gob.mx/cms/uploads/attachment/file/207252/Modelo_Educativo_OK.pdf

Stern, H. (1983). Fundamental concepts of language teaching. Oxford, UK: Oxford University Press.

Tarver, S., \& Curry, J. (1992). Gifted students in regular classrooms. In L. Cohen (Ed.), Children with exceptional needs in regular classrooms. Chapter 8. Washington, D.C.: National Education Association of the United States.

Tashakkori, A., \& Teddlie, C. (2003). Handbook of mixed methods in social \& behavioral research. Retrieved from https://books.google.cowm. $\mathrm{mx} /$ books? id=F8BFOM8DCKoC\&printsec=frontcover\&hl=es \& source=gbs_ge_summary_r\&cad=0\#v=onepage\&q\&f=false

Woolflok, A. (2010). Psicología educativa (11 ${ }^{\text {th }}$ Ed.). Naucalpan, Mexico: Pearson Educación.

Zavala, M. (2004). Desarrollo y validación de un sistema para la detección de alumnos con aptitudes sobresalientes-superdotados. Revista de Educación y Desarrollo, 13-20. Retrieved from http://www.cucs.udg. $\mathrm{mx} /$ revistas/edu_desarrollo/anteriores/3/003_Zavala.pdf 


\section{Appendix A}

Semi structured interview guide

70 Name:

School:

Age:

Male Female

1. How did you learn English?

2. When do you consider you learned English? When was your first contact?

3. How do you practice?

4. Who in your family speaks English?

5. In addition to English and Spanish, do you speak another language?

6. How do you consider your performance as student?

7. Has been the same performance since primary? Why?

8. Can you describe your English classes?

9. Which subject is the easiest for you? And the most difficult?

10. Do you want to study a major? Why?

11. How can English benefit your life?

12. Do you think English will help you in the future? How? 


\section{Appendix B}

Focus group guide

1. How do you consider your performance as student?

2. Have you had the same performance since primary school?? Why?

3. In addition to Spanish, do you speak another language?

4. When was your first contact with the English Language?

5. Do you practice this language? How?

6. Who in your family speak English?

7. Why do you think you obtained level A1 in the English test? How skillful do you consider yourself in this language?

8. In your opinion, how can you improve your English language?

9. Do you think English will help you in the future? How? 